\title{
Analysis of Compliance with Repairs of Hypertension Reviewed from Health Care Function and Implementation of Family Health Information Package
}

\begin{abstract}
Ahmad Zainal Abidin
Bojonegoro, Indonesia

Email:

ahmadzainalabidin819@yahoo.com

Received : March 12, 2019

ABSTRACT

Treatment compliance with patients with hypertension is a very important concern to approach morbidity and mortality due to hypertension and to improve the quality of life of patients with hypertension. this condition is inseparable from the existence of families who provide support in the form of their functions and the role of health workers in providing adequate services. The purpose of this study was to analyze treatment adherence to hypertension recipients in terms of health care function and the implementation of family health information package in Bulu village, Balen Bojonegoro district. The design of this study is a quantitative cross sectional approach with a simple random sampling technique as many as 109 respondents with hypertension who received a guided program and data analysis techniques using ordinal regression statistical tests. The results of this study indicate that there are effects of health care function and implementation of family health information package on treatment compliance of hypertensive patients with $\mathrm{p}$ value of ordinal regression test of 0,000 which is less than $\alpha=0.05$, meaning that $\mathrm{H} 0$ is rejected and $\mathrm{H} 1$ is accepted. Health care function has an effect of $41.2 \%$ and the implementation of family health information package has an effect of $48.7 \%$, and is influenced by other factors by $28.4 \%$. The influence of the family in the form of health care functions and health workers in the form of implementing family health information package proves the value of good treatment compliance in patients with hypertension, because patients feel more attention from various parties both internal and external.
\end{abstract}

Accepted: October 13, 2019

Published : November 26, 2019
Keywords : Health Care Function, Implementation Family Health Information Package, Compliance, Hypertension 


\section{INTRODUCTION}

Hypertension is a form of degenerative disease that is still a frightening figure in society. Abnormalities that occur in the flow and blood vessels are common in the community that unwittingly will be a condition capable of causing serious diseases with a significant impact on the health status of each individual, or can be interpreted as an increase in the workload of the heart and arteries which if it continues can lead to heart and blood vessel damage (Udjianti, 2011). Conditions like this are a neglect of unhealthy lifestyles, irregular and complete treatment of hypertension, and other co-morbidities that make the status of hypertension higher.

According to WHO (World Health Organization) and the international society of Hypertension (ISH), there are 600 million hypertensive sufferers worldwide, with 3 million of them dying each year with blood pressure above $140 / 90 \mathrm{mmHg}$ at two measurements and in a state of sufficient rest . Data from Indonesia's Health Profile in 2016, National prevalence for high blood pressure is $30.9 \%$. The prevalence of high blood pressure in women $(32.9 \%)$ was higher than that of men (28.7\%). Urban prevalence is slightly higher (31.7\%) compared to rural areas (30.2\%). Data from Profile East Java's Health in 2015, 685,994 people with hypertension in East Java (15.16\%) with 257,519 men (12.73\%) and 428,475 women $(17.11 \%)$. One of the biggest oil producing districts in East Java, Bojonegoro, the rate of hypertension cannot be underestimated. Based on data from Bojonegoro Health Profile, Bojonegoro with hypertension cases in the last 3 years, from 2014 there were 49,696 cases of hypertension, in 2015 there were 29,034 cases of hypertension and in 2016 there were 33,464 cases of hypertension. From the results of a preliminary study at the Balen health center in Bojonegoro District, there were $19.4 \%$ of hypertensive diseases and ranked 3rd out of the top 10 diseases and from the data recapitulation the number of control clients for hypertension was $58.6 \%$ or 236 of 403 patients per April 2018. In this case, from the observations of researchers, 6 out of 10 people with hypertension took medication if there were signs of symptoms, the family reminded them of the time to take medication and the drugs consumed were still available and did not change therapy or change medication.

Neglect of an irregular and complete treatment of hypertension will bring up new and serious problems such as; an increase in the degree of hypertension that will create new interventions in the treatment of hypertension with a degree that has changed (Muttaqin, 2012). The World Health Organization explains that the problem of neglect or non-compliance is significant, the compliance of clients with chronic or degenerative diseases is around 50\% in developed countries, while in countries develops lower, as in Indonesia, with a range of compliance with the use of anti-hypertensive drugs around 26-43\% (Niman, 2017). From the conditions encountered by researchers in the community, some patients changed their treatment interventions due to changes in the hypertension dejarat experienced, because previously the treatment was irregular and complete.

The awareness of each individual in fulfilling their health is the initial capital to maintain their health status. Individuals who when experiencing health problems and are reluctant to take medication or even are not regulated and complete, will unwittingly have a worse impact on themselves. A person with hypertension must undergo regular treatment and control to maintain his health status, so that the productivity of life is better (Effendi \& Chayatin, 2009).

This is inseparable from the extent to which a family is able to influence other family members in a family health. The health care function in a family will influence the good and bad health status of the family itself. Because the intensity of interaction and patterns of family development will be created in it for a decision making on a health problem in the family. Family function: health care function is a function to maintain the health of the family so that it still has high productivity and family ability in managing family and individual health (Efendi \& Makhfudi, 2009). As the result of research conducted by Koyongian et al. (2015), that the relationship of family with obedience or obedience of other family members who are sick in carrying out health management is necessary, so that the implementation of health management can be realized properly.

In addition, the active role of health workers in maintaining public health status is also very important. Health promotion programs with various methods and development strategies are the key to be able to create a new atmosphere in the world of promotive and preventive for public health. Like the existence of a healthy Indonesia program with a family approach (PIS_PK) which has been carried out in 1 target village (Desa Bulu) in the working area of the balen bojonegoro health center, the program which is the 5th agenda of Nawa Cipta is improving the quality of Indonesian human life. The target of this program one of which is to increase the control of diseases in both infectious and non-infectious 
categories. To achieve this, efforts are made in the form of promotive, educative, preventive, early detection activities, increased access to health services with family health profiles and family health information packages (PIS-PK Ministry of Health RI, 2016).

family health information package is a form of effort that emphasizes a series of aspects of promotive action in the community that aims to arouse awareness of the importance of health with various touches. The touch is expected to be a solution for the community to be more active in the utilization of health facilities and infrastructure. In this family health information package is in the form of health education facility packages in the form of flyers, leaflets, pocket books, etc. provided to families according to the health problems they face, such as hypertension flyers for those who suffer from hypertension. Furthermore, the family information package was delivered in the packaging of home visits, focus group discussions, UKBM counseling opportunities, and various forums that already exist in the community (Ministry of Health RI, 2017).

From this background, the researchers wanted to do an analysis of the family functions: health care function and implementation of family information packages in a healthy Indonesia program family approach to the adherence of hypertensive patients in doing treatment in Bulu Village Balen Bojonegoro Village.

\section{MATERIALS AND METHODS}

This study uses quantitative analytical methods using a cross sectional approach. The population in this study were hypertensive patients in the feather village of Balen Bojonegoro sub-district who received the assistance program from the Balen health center. The sample size in this study was 109 respondents using simple random sampling technique. The independent variables in this study were health care function and implementation of family health information package, Compliance, while the dependent variable was adherence to treatment for hypertensive patients. Data were collected using a questionnaire, then analyzed using ordinal regression test.

\section{RESULT}

Distribution of Respondent Characteristics

Tabel 1. Characteristics of Respondents by Age

\begin{tabular}{|c|c|c|c|c|c|}
\hline \multicolumn{6}{|c|}{ Age } \\
\hline & & Frequency & Percent & Valid Percent & Cumulative Percent \\
\hline \multirow{6}{*}{ Valid } & $18-28$ years & 11 & 10.1 & 10.1 & 10.1 \\
\hline & 29-39 years & 29 & 26.6 & 26.6 & 36.7 \\
\hline & $40-50$ years & 41 & 37.6 & 37.6 & 74.3 \\
\hline & 51-61 years & 19 & 17.4 & 17.4 & 91.7 \\
\hline & $>62$ years & 9 & 8.3 & 8.3 & 100.0 \\
\hline & Total & 109 & 100.0 & 100.0 & \\
\hline
\end{tabular}

Showed that out of 109 respondents, most of the hypertensive patients had ages between 40-50 years, as many as 41 respondents $(37.6 \%)$.

Tabel 2. Characteristics of Respondents by Gender

\begin{tabular}{|c|c|c|c|c|c|}
\hline \multicolumn{6}{|c|}{ Gender } \\
\hline & & Frequency & Percent & Valid Percent & Cumulative Percent \\
\hline \multirow{3}{*}{ Valid } & Male & 47 & 43.1 & 43.1 & 43.1 \\
\hline & Female & 62 & 56.9 & 56.9 & 100.0 \\
\hline & Total & 109 & 100.0 & 100.0 & \\
\hline
\end{tabular}

Shows that out of 109 respondents more than half of hypertensive patients were female, as many as 62 respondents $(56.9 \%)$. 
Tabel 3 Characteristics of Respondents Based on Marriage Status

\begin{tabular}{cccccc}
\hline \multicolumn{7}{c}{ Marriage Status } \\
\hline \multirow{4}{*}{ Valid } & \multicolumn{7}{c}{ Frequency } & Percent & Valid Percent & Cumulative Percent \\
\hline & Married & 67 & 61.5 & 61.5 & 61.5 \\
\cline { 2 - 7 } & Widow & 29 & 26.6 & 26.6 & 88.1 \\
\cline { 2 - 7 } & Widower & 13 & 11.9 & 11.9 & 100.0 \\
\cline { 2 - 7 } & Total & 109 & 100.0 & 100.0 & \\
\hline
\end{tabular}

Showed that out of 109 respondents, most of the patients with hypertension were married, as many as 67 respondents $(61.5 \%)$.

Tabel 4 Characteristics of Respondents Based on Education Status

\begin{tabular}{cccccc}
\hline \multicolumn{5}{c}{ Education Status } \\
\hline \multirow{4}{*}{ Valid } & Frequency & Percent & Valid Percent & Cumulative Percent \\
\cline { 2 - 7 } & Primary school & 18 & 16.5 & 16.5 & 16.5 \\
\cline { 2 - 6 } & Junior high school & 41 & 37.6 & 37.6 & 54.1 \\
\cline { 2 - 6 } & Senior high school & 47 & 43.1 & 43.1 & 97.2 \\
\cline { 2 - 6 } & College & 3 & 2.8 & 2.8 & 100.0 \\
\cline { 2 - 6 } & Total & 109 & 100.0 & 100.0 & \\
\hline
\end{tabular}

Showed that out of 109 respondents, most hypertensive patients with senior high school education were 47 respondents $(43.1 \%)$.

Tabel 5 Characteristics of Respondents by works

\begin{tabular}{ccccccc}
\hline \multicolumn{7}{c}{ Works } \\
\hline \multirow{4}{*}{ Valid } & & Frequency & Percent & Valid Percent & Cumulative Percent \\
\hline & Work & 70 & 64.2 & 64.2 & 64.2 \\
\cline { 2 - 7 } & Retirement & 1 & .9 & .9 & 65.1 \\
\cline { 2 - 7 } & Housewie & 38 & 34.9 & 34.9 & 100.0 \\
\cline { 2 - 7 } & Total & 109 & 100.0 & 100.0 & \\
\hline
\end{tabular}

Showed that out of 109 respondents more than some hypertensive patients with working status, as many as 70 respondents $(64.2 \%)$.

Tabel 6 Characteristics of Respondents Based on the Length of Diagnosis of Hypertension

\begin{tabular}{cccccc}
\hline \multicolumn{5}{c}{ Length of Diagnosis of Hypertension } \\
\hline & Frequency & Percent & Valid Percent & Cumulative Percent \\
\hline \multirow{3}{*}{ Valid } & \multicolumn{1}{c}{ 1 years } & 3 & 2.8 & 2.8 & 2.8 \\
\cline { 2 - 6 } & $1-2$ years & 27 & 24.8 & 24.8 & 27.5 \\
\cline { 2 - 6 } & $2-3$ years & 41 & 37.6 & 37.6 & 65.1 \\
\cline { 2 - 6 } & $3-4$ years & 32 & 29.4 & 29.4 & 94.5 \\
\cline { 2 - 6 } & $>5$ years & 6 & 5.5 & 5.5 & 100.0 \\
\cline { 2 - 6 } & Total & 109 & 100.0 & 100.0 & \\
\hline
\end{tabular}

Showed that out of 109 respondents, most patients with hypertension were diagnosed for 2-3 years, namely 41 respondents $(37.6 \%)$. 
Tabel 7 Characteristics of Respondents Based on Hypertension History Family

\begin{tabular}{|c|c|c|c|c|c|}
\hline \multicolumn{6}{|c|}{ Hypertension History Family } \\
\hline & & Frequency & Percent & Valid Percent & Cumulative Percent \\
\hline \multirow{3}{*}{ Valid } & There is a history & 53 & 48.6 & 48.6 & 48.6 \\
\hline & No history & 56 & 51.4 & 51.4 & 100.0 \\
\hline & Total & 109 & 100.0 & 100.0 & \\
\hline
\end{tabular}

Showed that out of 109 respondents more than some hypertensive patients with families who did not have a history of hypertension as many as 56 respondents $(51.4 \%)$.

Tabel 8 Characteristics of Respondents Based on Duration of Therapy

\begin{tabular}{|c|c|c|c|c|c|}
\hline \multicolumn{6}{|c|}{ Duration of Therapy } \\
\hline & & Frequency & Percent & Valid Percent & Cumulative Percent \\
\hline \multirow{6}{*}{ Valid } & $<1$ years & 3 & 2.8 & 2.8 & 2.8 \\
\hline & $1-2$ years & 27 & 24.8 & 24.8 & 27.5 \\
\hline & $2-3$ years & 41 & 37.6 & 37.6 & 65.1 \\
\hline & 3-4 years & 32 & 29.4 & 29.4 & 94.5 \\
\hline & $>5$ years & 6 & 5.5 & 5.5 & 100.0 \\
\hline & Total & 109 & 100.0 & 100.0 & \\
\hline
\end{tabular}

Showed that out of 109 respondents, most patients with hypertension with 2-3 years of therapy were 41 respondents $(37.6 \%)$.

Tabel 9 Characteristics of Respondents Based on Control History

\begin{tabular}{cccccc}
\hline \multicolumn{5}{c}{ Control History } \\
\hline & $\begin{array}{c}\text { Frequen } \\
\text { cy }\end{array}$ & Percent & $\begin{array}{c}\text { Valid } \\
\text { Percent }\end{array}$ & Cumulative Percent \\
\hline \multirow{3}{*}{ Valid } & Independent health services & 17 & 15.6 & 15.6 & 15.6 \\
\cline { 2 - 6 } & community Health centers & 89 & 81.7 & 81.7 & 97.2 \\
\cline { 2 - 6 } & Hospital & 2.8 & 2.8 & 100.0 \\
\cline { 2 - 6 } & Total & 109 & 100.0 & 100.0 & \\
\hline
\end{tabular}

Showed that out of 109 respondents, the majority of hypertensive patients with a control history at the health center were 89 respondents $(81.7 \%)$.

Tabel 10 Characteristics of Respondents Based on Drug Taking

\begin{tabular}{cccccc}
\hline \multicolumn{5}{c}{ Drug Taking } \\
\hline & Frequency & Percent & Valid Percent & Cumulative Percent \\
\hline \multirow{3}{*}{ Valid } & Independent health services & 17 & 15.6 & 15.6 & 15.6 \\
\cline { 2 - 6 } & community Health centers & 89 & 81.7 & 81.7 & 97.2 \\
\cline { 2 - 6 } & Hospital & 3 & 2.8 & 2.8 & 100.0 \\
\hline Total & 109 & 100.0 & 100.0 & \\
\hline
\end{tabular}

Showed that out of 109 respondents, the majority of hypertensive patients took medication at the community Health centers which were 89 respondents $(81.7 \%)$. 
Tabel 11 Characteristics of Respondents by Type of Drug

\begin{tabular}{cccccc}
\hline \multicolumn{6}{c}{ Type of Drug } \\
\hline \multirow{3}{*}{ Valid } & \multicolumn{6}{c}{ Frequency } & Percent & Valid Percent & Cumulative Percent \\
\cline { 2 - 7 } & Captopril & 91 & 83.5 & 83.5 & 83.5 \\
\cline { 2 - 7 } & Candesartan & 5 & 4.6 & 4.6 & 88.1 \\
\cline { 2 - 6 } & Bisoprolol & 9 & 8.3 & 8.3 & 96.3 \\
\cline { 2 - 6 } & Amlodipin & 4 & 3.7 & 3.7 & 100.0 \\
\cline { 2 - 6 } & Total & 109 & 100.0 & 100.0 & \\
\hline
\end{tabular}

Showed that out of 109 respondents, the majority of hypertensive patients consumed captopril, which was 91 respondents $(83.5 \%)$.

Tabel 12 Characteristics of Respondents Based on Blood Pressure

\begin{tabular}{|c|c|c|c|c|c|}
\hline \multicolumn{6}{|c|}{ Blood Pressure } \\
\hline & & Frequency & Percent & Valid Percent & Cumulative Percent \\
\hline \multirow{3}{*}{ Valid } & hypertension 1 & 51 & 46.8 & 46.8 & 46.8 \\
\hline & hypertension 2 & 58 & 53.2 & 53.2 & 100.0 \\
\hline & Total & 109 & 100.0 & 100.0 & \\
\hline
\end{tabular}

Showed that from 109 respondents more than part of hypertensive patients with hypertension status of level 2, as many as 58 respondents (53.2\%).

Variable Characteristic Distribution

Tabel 13 Frequency Distribution Based on Health Care Function

\section{Healt Care Function}

\begin{tabular}{cccccc}
\hline & & Frequency & Percent & Valid Percent & Cumulative Percent \\
\hline \multirow{3}{*}{ Valid } & Good & 31 & 28.4 & 28.4 & 28.4 \\
\cline { 2 - 6 } & Enough & 75 & 68.8 & 68.8 & 97.2 \\
\cline { 2 - 6 } & Less & 3 & 2.8 & 2.8 & 100.0 \\
\cline { 2 - 6 } & Total & 109 & 100.0 & 100.0 & \\
\hline
\end{tabular}

Showed that out of 109 respondents more than a part of hypertensive patients got enough health care functions from the family, as many as 75 respondents $(68.8 \%)$.

Tabel 14 Frequency Distribution Based on Implementation family health information package

\begin{tabular}{|c|c|c|c|c|c|}
\hline \multicolumn{6}{|c|}{ Implementation family health information package } \\
\hline & & Frequency & Percent & Valid Percent & Cumulative Percent \\
\hline \multirow{4}{*}{ Valid } & Good & 21 & 19.3 & 19.3 & 19.3 \\
\hline & Enough & 83 & 76.1 & 76.1 & 95.4 \\
\hline & Less & 5 & 4.6 & 4.6 & 100.0 \\
\hline & Total & 109 & 100.0 & 100.0 & \\
\hline
\end{tabular}

Showed that out of 109 respondents, most of the hypertensive patients got enough information in the form of family health information package from health workers, namely 83 respondents $(76.1 \%)$. 
Tabel 15 Frequency Distribution Based on Compliance Treatment Patients with hypertension

\begin{tabular}{|c|c|c|c|c|c|}
\hline \multicolumn{6}{|c|}{ Compliance Treatment Patients with hypertension } \\
\hline & & Frequency & Percent & Valid Percent & Cumulative Percent \\
\hline \multirow{4}{*}{ Valid } & High & 14 & 12.8 & 12.8 & 12.8 \\
\hline & Medium & 64 & 58.7 & 58.7 & 71.6 \\
\hline & Low & 31 & 28.4 & 28.4 & 100.0 \\
\hline & Total & 109 & 100.0 & 100.0 & \\
\hline
\end{tabular}

Showed that out of 109 respondents more than half of patients with hypertension adherence to treatment were in the medium category, namely 64 respondents $(58.7 \%)$.

Multivariate analysis with ordinal regression

Tabel 16 Model Fitting Information

\begin{tabular}{ccccc}
\hline \multicolumn{5}{c}{ Model Fitting Information } \\
\hline Model & -2 Log Likelihood & Chi-Square & Df & Sig. \\
\hline Intercept Only & 77.466 & & & \\
\hline Final & 19.640 & 57.826 & 4 & .000 \\
\hline
\end{tabular}

Shows that the results of statistical tests performed with ordinal regression to 109 respondents using a 0.05 degree of error and the results obtained $p$ value of 0.000 . If the $p$ value <degree of error, then the hypothesis is accepted which means that there is an influence from the health care function and the implementation of family health information package with respect to treatment compliance with hypertension patients in the fur village of Balen Bojonegoro district.

\section{DISCUSSION}

\section{Effect of Health Care Functions on Treatment Compliance of Hypertension Patients in Bulu} Village, Balen Bojonegoro District

The results of this study indicate that out of 109 respondents there were 48 respondents (44\%) had adherence to being treated for hypertension by getting enough health care functions from their families, 14 respondents (12.8\%) had high adherence to hypertension treatment by getting a health care function good from family.

A family must be able to recognize the health problems of his family, the extent to which the family knows the facts of health problems such as; understanding, symptom signs, causes and influencing family principles towards family. In addition, family members are also required to be able to care for sick family members, meaning that the family knows the condition of the disease, knows the nature and development of care needed, knows the resources in the family and knows the facilities needed for care and family attitudes towards illness (Harmoko , 2012).

From the above researchers assume that family function, namely health care function is needed by hypertensive patients because of the complex problems faced by hypertensive patients, whether it is about their own disease, the side effects of drugs that must be consumed and also helplessness in higher hypertensive conditions. With the function of this family, hypertension sufferers will feel more calm and some remind / strengthen to take medicine and pay attention to the condition of hypertension as recommended by him.

The family will always support every member of his family who experiences pain, whatever the form of his pocket. Patients with hypertension who are not known for their hypertension status by the family, if they are sick will still get attention from the family, it would be better if all forms of health are known by each other family members to be able to pay more attention to the health of family members. Because it is realized or not that everyone will return to his family when they experience problems one of which is health and also death. Openness for people with hypertension in their families will be better to reduce the psychological burden they experience, pain, side effects of drugs and others that all sufferers of natural hypertension vary.

The form of the family function above shows that its presence is very important, this is not only for his family, but can also be a pioneer for the health of other family members. This means that if there is a good family at a point in the area for a good change for health, then the other family members will 
be motivated to increase awareness in a healthy life. Of course this stimulation also has a large and positive impact on public health at large.

\section{The Effect of Implementation Of Family Health Information Package on Compliance Treatment for Hypertension Patients in Bulu Village, Balen Bojonegoro District}

The results of this study indicate that from 109 respondents there were 51 respondents (46.8\%) had adherence to being treated for hypertension by getting enough FHIP implementation from health workers, 8 respondents $(7.3 \%$ ) had high adherence to hypertension treatment by getting implementation of family health information package is good from health workers.

The implementation of family health information package done by health workers to the community determines how the community, family or individuals to maintain their health. The role of health workers in the community is the extent to which they are able to run as health providers in the form of family nurse practitioners who are responsible for promotive and preventive efforts to limit the decline in health status and complications / records (Mubarak, W.I \& Chayatin, N, 2013).

The process carried out by health workers in the family in the form of counseling / education is to help families in expressing the problems they experience, helping families make joint decisions in an effort to find solutions in accordance with the sources owned by the family, and to help families in implementing solutions gradually in accordance with outcome of the agreement (Fredman, Bowed \& Jones, 2003 in Susanto, T, 2012).

From the reality above the researcher argues that the presence of a health worker in his form to convey what is his duty in a health is very meaningful in this case related to a compliance. Patients with hypertension who have a high level of adherence describe the implementation of family health information package both by health workers while a low level of adherence illustrates that the implementation of family health information package is enough even some are lacking. Compliance with treatment is not only determined by the amount taken on that day, but also the timeliness and regularity. Patients with hypertension who get a pink or not even get pink are at risk for a low level of compliance and can not even obey.

Patients with hypertension who have gotten pink, but for treatment compliance is still even low. An antihypetency drug that functions to stabilize blood pressure in the body of a hypertensive patient. this drug is not able to quickly eliminate high blood pressure from the body. Meanwhile, if the condition of blood pressure that is not controlled will have a serious impact on the health of patients with hypertension. If hypertension sufferers are not treated properly, it can be possible that the condition of blood pressure will be worse which affects the condition of morbidity and even mortality in patients with hypertension.

Changes in blood pressure conditions that are worse must be avoided, considering the blood vessels in hypertensive patients are very easy for problems and also for other organs. So that if a hypertensive patient who has adherence who is not supposed to be even disobedient in undergoing treatment then there is a possibility that the pharmacological therapy process will also change due to changes in hypertension that occur from before. Because when the development of science related to the determination of the diagnosis of hypertension and its treatment, the problem will also affect other factors which can become new problems for hypertensive sufferers, such as the availability of new drugs, prices and adjustments to patients, even though it has good benefits. for people with hypertension to suppress the morbidity aspects caused by hypertension.

\section{Effect of Health Care Function and Implementation of Family Health Information Package on} Compliance with Treatment for Hypertension Patients in Bulu Village, Balen Bojonegoro District

The results of this study indicate that from 109 respondents with ordinal regression statistical test process with fitting information model and estimates parameter obtained $p$ value of 0,000 which indicates that the value is less than the meaning of error that is 0.05 which means the hypothesis is accepted, besides the value of psuedo $r$ square shows the results that, the independent variables namely health care function and implementation of family health information package also have an influence on the dependent variable, namely adherence to treatment for hypertensive patients by $41.2 \%$ and $48.7 \%$ respectively.

This research is in line with what was stated by Andarmoyo, S (2012) that the ability of families to carry out their tasks in a health care function is that families are able to recognize health problems, 
make decisions for health actions, care for sick members, become environmental creators good and healthy for families and use of health facilities in the local environment. The results of the interim research of the PIS-PK program conducted in the southern Lampung district by the 3rd FIT Center for Health Resources \& Health Services IAKMI (2017) illustrates that it is useful to answer the findings of problems that exist in the family / community and provide recommendations related to the implementation of family health information package can be done parallel during home visits. This also provides a common thread in the research that researchers have done.

From the description above, the researcher believes that families with their health care function and family health information package implementation have contributed to treatment compliance in patients with hypertension. In improving the adherence to antihypertensive medication, hypertensive patients need a family function, namely health care function. Functions that are capable of monitoring the treatment of hypertensive patients such as; reminded times of taking medicine, recognizing the condition of changes in symptoms of hypertension, information support and the process of utilizing health facilities that are very important for hypertensive patients.

The implementation of family health information package obtained by hypertension sufferers from health workers has a positive impact on patients and families. With this breakthrough, making a new discourse in the world of health for health in the community in improving public health. The implementation which emphasizes more on aspects of educative and preventive is able to provide a new color for hypertensive sufferers to be more enthusiastic in the treatment process, so that those who are initially reluctant and taboo about their hypertension status and also the treatment process they undergo, are now more motivated to life is more aware that sick does not mean doing nothing, sick does not mean unproductive. So even though with a state of hypertension status they can still enjoy the quality of life well by keeping the treatment process they undergo.

Compliance in antihypertensive treatment is a joint task between sufferers, families and health workers as well as the activity of the community in it. Involvement will all provide more powerful energy for patients with hypertension in undergoing antihypertensive treatment. Not only that, other conditions that are a factor for adherence for patients with hypertension must also be considered such as socioeconomic, severity, psychosocial factors. So that this can suppress the conditions of morbidity and even mortality caused by cases of hypertension. In addition, it is expected that the value of quality of life for patients with hypertension is better and maintained with hypertension that is in them

\section{CONCLUSION}

From the results of the study, it was found that there was an effect of health care function and implementation of family health information package on medication compliance with hypertensive patients in the bulu village of Balen Bojonegoro district.

\section{REFERENCES}

Andarmoyo, \& Sulistyo. (2012). Keperawatan Keluarga. Yogyakarta: Graha Ilmu.

Arifin, S., \& Heriyani, F. (2014). Kapita Selekta Ilmu Kesehatan Masyarakat. Banjarmasin: In Media.

Brunnert, \& Suddart. (2014). Buku ajar keperawatan medikal bedah edisi 12. Jakarta: EGC.

Efendi, Ferry, \& Makhfudli. (2009). Keperawatan Kesehatan Komunitas. Jakarta: Salemba Medika.

Efendi, F., \& Chayatin, N. (2009). Keperawatan Kesehatan Komunitas I. Jakarta: Salemba Medika.

Harmoko. (2012). Asuhan Keperawatan Keluarga. Yogyakarta: Pustaka Pelajar.

Hidayat, \& Alimul, A. (2012). Metodologi Penelitian Keperawatan Dan Teknik Analisis Data. Jakarta : Salemba Medika.

Kemenkes RI. (2016). Program Indonesia Sehat dengan Pendekatan Keluarga. 
Kemenkes RI. (2017). Pedoman Monitoring dan Evaluating Pelaksanaan Program Indonesia Sehat Pendekatan Keluarga (PIS-PK).

Klabunde, R., E. (2015). Konsep Fisiologi Kardiovaskuler Edisi 2. Jakarta: EGC.

Konita, \& Saskia. (2015). pola tekanan darah pada lansia di posyandu lansia kelurahan padang pasir, Padang: jurnal kesehatan andalas vol.4 No.1.

Koyongian, A., S., dkk. (2015). Hubungan Peran Keluarga dengan Kepatuhan Berobat Pasien Hipertensi di Desa Batu Kecamatan Likupang Selatan Kabupaten Minahasa Utara. Manado: eJournal Keperawatan (eKp), Vol. 3, No.3.

Kurniawati, \& Widiatie, W. (2016). Pengaruh Pendidikan Kesehatan Terhadap Kepatuhan Diet Pada Penderita Hipertensi. Jombang: THE INDONESIAN JOURNAL OF HEALTH SCIENCE, Vol. 7, No. 1.

Liberty, \& Iche, A., dkk. (2017). Determinan Kepatuhan Berobat Pasien Hipertensi Pada Fasilitas Kesehatan Tingkat I. Palembang: Jurnal Penelitian dan Pengembangan Pelayanan Kesehatan, Vol.1, No.1.

Masriadi. (2016). Epidemiologi Penyakit Tidak Menular. Jakarta: Penerbit Trans info media.

Mubarak, W., I., \& Chayatin, N. (2009). Ilmu Kesehatan Masyarakat: Teori dan Praktik. Jakarta: Salemba Medika.

Mubarak, W., I., \& Chayatin, N. (2013). Ilmu Keperawatan Komunitas Pengantar dan Teori. Jakarta: Salemba Medika.

Mubin, A., \& Halim. (2016). Panduan Praktis Ilmu Penyakit Dalam, Diagnosis dan Terapi Edisi 3. Jakarta: EGC.

Muttaqin, A. (2012). Asuhan Keperawatan Klien dengan Gangguan Sistem Kardiovaskular. Jakarta: Salemba Medika.

NANDA. (2018). Diagnosis Keperawatan Definisi dan Klasifikasi. Jakarta: EGC.

Niman, S. (2017). Promosi dan Pendidikan Kesehatan. Jakarta: CV. TRANS INFO MEDIA.

Nursalam. (2016). Metodologi Penelitian Ilmu Keperawatan. Edisi 4. Jakarta: Salemba Medika.

Profil Kesehatan Bojonegoro (2014). Diakses pada 9 Juni 2018, http://www.depkes.go.id/resources/download/profil/PROFIL_KAB_KOTA_2014/3522_Jatim _Kab_Bojonegoro_2014.pdf.

Profil Kesehatan Bojonegoro (2015). Diakses pada 9 Juni 2018, http://www.depkes.go.id/resources/download/profil/PROFIL KAB KOTA 2015/3522 Jatim _Kab_Bojonegoro_2015.pdf.

Profil Kesehatan Bojonegoro (2016). Diakses pada 9 Juni 2018, http://www.depkes.go.id/resources/download/profil/PROFIL KAB KOTA 2016/3522 Jatim _Kab_Bojonegoro_2016.pdf.

Profil Kesehatan Indonesia (2016). Diakses pada 9 Juni 2018, http://www.depkes.go.id/resources/download/pusdatin/profil-kesehatan-indonesia/Profil-

Kesehatan-Indonesia-2016.pdf. 
Profil Kesehatan Jawa Timur (2015). Diakses pada 9 Juni 2018, http://dinkes.jatimprov.go.id/userfile/dokumen/PROFIL\%20KES_2015.pdf.

Puslitbang Sumber Daya \& Pelayanan Kesehatan FIT ke-3 IAKMI. (2017). Hasil (Sementara) riset implementasi PIS-PK di Kabupaten Lampung Selatan.

Ramadhan, A., J. (2010). Mencegah Berbagai Gangguan pada Darah dan Pembuluh Darah. Jogjakarta: DIVA Press (Anggota IKAPI).

Sahara, dkk. (2013). Harmonious Family. Jakarta: Yayasan Pustaka Obor Indonesia.

Sudarta, \& I Wayan. (2013). Asuhan Keperawatan Klien dengan Gangguan Sistem Cardiovaskuler. Yogyakarta: Pustaka Baru.

Supartini, Y. (2012). Buku Ajar Konsep Dasar Keperawatan Anak. Jakarta: EGC.

Susanto, T. (2012). Buku Ajar Keperawatan Keluarga. Jakarta: Trans Info Media.

Udjianti, W., J. (2011). Keperawatan Kardiovaskuler. Jakarta: Salemba Medika.

Whelton, Paul K, dkk. (2017). 2017 Guideline for the Prevention, Detection, Evaluation, and Management of Hight Blood Pressure in Adults. Amerika: ACC.

Zaidin, \& Ali. (2009). Pengantar Keperawatan Keluarga. Jakarta: EGC. 